\title{
ESTIMATION OF TASK COMPLETION TIMES WITH THE USE OF THE PERT METHOD ON THE EXAMPLE OF A REAL CONSTRUCTION PROJECT
}

\author{
E. PLEBANKIEWICZ1 ${ }^{1}$, M. JUSZCZYK ${ }^{2}$, J. MALARA ${ }^{3}$
}

\begin{abstract}
The article presents briefly several methods of working time estimation. However, three methods of task duration assessment have been selected to investigate working time in a real construction project using the data collected from observing workers laying terrazzo flooring in staircases. The first estimation has been done by calculating a normal and a triangular function. The next method, which is the focus of greatest attention here, is PERT. The article presents a way to standardize the results and the procedure algorithm allowing determination of the characteristic values for the method. Times to perform every singular component sub-task as well as the whole task have been defined for the collected data with the reliability level of $85 \%$. The completion time of the same works has also been calculated with the use of the KNR. The obtained result is much higher than the actual time needed for execution of the task calculated with the use of the previous method. The authors argue that PERT is the best method of all three, because it takes into account the randomness of the entire task duration and it can be based on the actual execution time known from research.
\end{abstract}

Keywords: PERT method, working time

\section{INTRODUCTION}

During the implementation of building projects the right balance must be found between time, cost and quality. A more extensive discussion of the relationship between them may be found in

\footnotetext{
${ }^{1}$ Prof., DSc., PhD., Eng., Cracow University of Technology, Faculty of Civil Engineering, Ul. Warszawska 24, 31-155 Cracow, Poland, e-mail: eplebank@izwbit.pk.edu.pl

${ }^{2}$ PhD., Eng., Cracow University of Technology, Faculty of Civil Engineering, Ul. Warszawska 24, 31-155 Cracow, Poland, e-mail: mjuszczyk@izwbit.pk.edu.pl

${ }^{3}$ MSc., Eng., Cracow University of Technology, Faculty of Civil Engineering, Ul. Warszawska 24, 31-155 Cracow, Poland, e-mail: jmalara@izwbit.pk.edu.pl
} 
Kuprenas [9]. Proper planning of a project execution includes selecting the technologies which are to be used, carefully dividing the tasks and responsibilities, estimating the required resources and duration of each activity and determining all possible interactions between various tasks [6].

A well thought-out construction plan requires careful analysis of all the factors affecting the project. It is necessary to define the most important activities, key terms of their implementation and the order of their execution [2].

In the present article, the authors will focus on the measurement of time necessary for construction workers to complete the task they have been assigned. It is one of the most important elements in the process of building project planning. An accurate estimate of the execution time of each task enables more efficient implementation of tasks related to the construction. The results will be subject to analysis with the use of the PERT method.

The article is a continuation of the research subject previously investigated by one of the authors. Its results were presented in an earlier publication [7]. The authors are looking for the best method to predict how long given construction works are going to take.

\section{TIME ESTIMATION OF THE TASKS}

Estimation of the duration of a task is a very important element of planning and realization of any construction project. The knowledge of how much time is really needed to complete a task enables efficient management and gives the possibility to react if there is a danger of missing a deadline. The completion time may be estimated using numerous methods, among which the following ones are worth mentioning:

- Delphi method,

- COCOMO II,

- Use Case Points,

- PERT,

- Probability distribution function,

- Katalogi Nakładów Rzeczowych /Material Expenditure Catalogues/.

The advantage of the Delphi method [5] is participation of experts in assessing the time of task realization. The method comprises seven steps of the procedure algorithm for collecting experts' opinions. If the opinions differ considerably, it is necessary to repeat interviewing the experts until the opinions become as convergent as possible. The procedure is completed by making a final estimation, which is the weighted average of the collected opinions, and the key importance is 
attributed to the mean assessment. An important feature of the Delphi method ensuring its objective character is the anonymity of experts, who cannot communicate with each other. All results are collected by an independent person - a moderator.

The computer approach to estimation of task duration includes the method called COCOMO II [1], which is an updated version of COCOMO. The assessment of the task execution time is based on existing factors calibrated with the use of the data collected from161 realizations. The time is determined on the basis of its primary value (average) adjusted by taking into account the factors which affect task completion times and according to their impact on these times. The base of the factors has been built outside Poland and does not include Polish realizations, which could explain why it does not reflect adequately the realities of the domestic building market.

The Use Case Point method [8] is based on correcting the sum of the expected capacity factors that make up the scaled measured value factor multiplied by their weight. It is easier to use because calculation is simpler when compared with COCOMO II, but it also requires determination of the average time of the task.

\subsection{THE PERT METHOD}

The PERT method (Program Evaluation and Review Technique), which will be used for calculations later on in the article, was developed in the United States in 1956-1957. Duration of an activity is seen in this method as a random variable having the following parameters:

- a - optimistic time required to accomplish a task,

- $\mathrm{m}$ - the most probable time required to accomplish a task,

- $\quad b-$ pessimistic time required to accomplish a task.

Based on the characteristic parameters of the distribution, the value of the estimated time tp is determined according to the following formula:

$$
t_{p}=\frac{a+4 m+b}{6}
$$

According to the needs, there is a possibility to correct the weighting factors for times a, $\mathrm{m}, \mathrm{b}$, while ratio 1:4:1 is the most common. The estimated time tp (2.1) is used to analyze the critical path in the same way as CPM (Critical Path Method). Parameters a and b are also used to calculate variance (2.2). 


$$
\sigma^{2}=\left(\frac{a+b}{6}\right)^{2}
$$

Determination of probability in the PERT method starts with establishing the value of factor $\mathrm{W}$ (2.3) and with calculating the critical path using the predetermined expected time tp.

$$
W=\frac{T_{D}-t_{z(i, j)}^{n w}}{\sqrt{\sum \sigma_{(i, j)}^{2}}}
$$

where:

$\mathrm{W}$ - probability factor, $T_{D}$ - directly imposed time to complete the task, $t_{z(i, j)}^{n w}$ - the first deadline

for completion of the i-j (according to CPM), $\sum \sigma_{(i, j)}^{2}$ - sum of the variance of processes whose execution times are included in the calculation $t_{z(i, j)}^{n w}$.

The values of probability for the calculated probability factor $\mathrm{W}$ are included in the tables of standardized normal distribution. After conversion of the formula, it is possible to determine the time of the task completion with a given accuracy level.

\subsection{EXAMPLE OF THE MATHEMATICAL PROBABILITY DISTRIBUTION FUNCTION APPLICATION}

In article [7] the authors present a method of predicting the time of completion of certain activities using the normal and triangular distribution function. The estimated parameters of the distributions are set together in Table 1 ( $\hat{\mathrm{t}}_{\mathrm{e}}$ stands for estimated expected value and $\widehat{\sigma}$ for estimated standard deviation).

It is noteworthy that the expected values for both distributions are quite similar for all three construction works. Standard deviations differ to some extent, but it is the result of the differences in shape of the two types of distributions. 
Table 1.Estimated parameters of triangular and normal distribution of the construction works duration.

\begin{tabular}{|c|c|c|c|c|c|c|c|}
\hline \multirow{2}{*}{ Type of work } & \multicolumn{5}{|c|}{ Triangular distribution parameters } & \multicolumn{2}{c|}{ Normal distribution parameters } \\
\cline { 2 - 8 } & $\hat{a}=\min \{t\}$ & $\hat{m}=\operatorname{mode}\{t\}$ & $\hat{b}=\max \{t\}$ & $\hat{t}_{e}$ & $\hat{\sigma}$ & $\hat{t}_{e}$ & $\hat{\sigma}$ \\
\hline $\begin{array}{c}\text { Execution of the } \\
\text { floor covering }\end{array}$ & 3 & 5 & 6 & 4.67 & 0.624 & 4.82 & 0.820 \\
\hline $\begin{array}{c}\text { Preparation of } \\
\text { landings and } \\
\text { corridors }\end{array}$ & 5 & 7 & 8 & 6.67 & 0.624 & 7.13 & 1.019 \\
\hline $\begin{array}{c}\text { Laying the floor } \\
\text { covering on landings }\end{array}$ & 4 & 5 & 6 & 5.00 & 0.408 & 4.86 & 0.622 \\
\hline
\end{tabular}

On the basis of the analysis it is possible to assess the completion times for the three construction works. The approximations of triangular and normal distributions allow us both to assume the duration and assess the probability of completion of certain construction work within the assumed period of time. Example assumptions are presented in Table 2.

Table 2. Assumed durations and their probabilities.

\begin{tabular}{|c|c|c|c|c|c|c|}
\hline \multirow{2}{*}{ Type of work } & \multicolumn{5}{|c|}{ Example 1 } & \multicolumn{3}{c|}{ Example 2 } \\
\cline { 2 - 7 } & $\begin{array}{c}\text { Assumed } \\
\text { duration } \\
\text { [days] }\end{array}$ & $\begin{array}{c}\text { Probablity }- \\
\text { triangular } \\
\text { distrubution }\end{array}$ & $\begin{array}{c}\text { Probablity }- \\
\text { normal } \\
\text { distrubution }\end{array}$ & $\begin{array}{c}\text { Assumed } \\
\text { duration } \\
\text { [days] }\end{array}$ & $\begin{array}{c}\text { Probablity - } \\
\text { triangular } \\
\text { distrubution }\end{array}$ & $\begin{array}{c}\text { Probablity }- \\
\text { normal } \\
\text { distrubution }\end{array}$ \\
\hline $\begin{array}{c}\text { Execution of } \\
\text { the floor } \\
\text { covering }\end{array}$ & 4 & $\mathrm{P}(\mathrm{t} \leq 4)=0.168$ & $\mathrm{P}(\mathrm{t} \leq 4)=0.159$ & 5 & $\mathrm{P}(\mathrm{t} \leq 5)=0.670$ & $\mathrm{P}(\mathrm{t} \leq 5)=0.587$ \\
\hline $\begin{array}{c}\text { Preparation } \\
\text { of landings } \\
\text { and corridors }\end{array}$ & 6 & $\mathrm{P}(\mathrm{t} \leq 6)=0.168$ & $\mathrm{P}(\mathrm{t} \leq 6)=0.134$ & 7 & $\mathrm{P}(\mathrm{t} \leq 7)=0.670$ & $\mathrm{P}(\mathrm{t} \leq 7)=0.449$ \\
\hline $\begin{array}{c}\text { Laying the } \\
\text { floor } \\
\text { covering on } \\
\text { landings }\end{array}$ & 5 & $\mathrm{P}(\mathrm{t} \leq 5)=., 500$ & $\mathrm{P}(\mathrm{t} \leq 5)=0.589$ & 6 & $\mathrm{P}(\mathrm{t} \leq 6)=1.000$ & $\mathrm{P}(\mathrm{t} \leq 6)=0.967$ \\
\hline
\end{tabular}

The same data that were used for calculations whose results are presented in Tables 1 and 2 were also used in Section 3 of this article.

\section{APPLICATION OF PERT}

\subsection{RESEARCH DESCRIPTION}

The analyzed data come from the research done using the timing method in one of the currently ongoing construction projects in Warsaw. The observed workers were assigned the comprehensive task of laying terrazzo flooring on the staircases and in the corridors of several blocks of flats. One team was performing the same works in ten similar staircases, using the same technology. For the 
needs of a more detailed analysis eight sub-tasks have been identified within the work: preparatory work, installation of steps, landings adjustment, installation of landings, installation of stair plinths, installation of plinths on landings, grouting, silicone sealing. The sequence of technological operations is presented in Diagram 1. Preparatory works are not included because they preceded each of the subsequent actions. The data which are the basis for the analysis are presented in Table 3. All data were collected using the timing method.



Diagram 1. The sequence of steps in the adopted technology. A - execution of the floor covering, $\mathrm{B}$ - preparation of landings, $\mathrm{C}$ - laying the terrazzo flooring on landings, $\mathrm{D}$ - installation of plinths on landings, $\mathrm{E}$ - installation of stair plinths, F - grouting, G - silicone sealing.

Table 3. Data obtained from research

\begin{tabular}{|c|c|c|c|c|c|c|c|c|c|c|c|c|c|c|}
\hline \multirow[t]{2}{*}{ 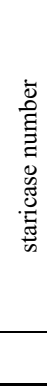 } & \multirow[t]{2}{*}{ 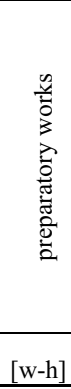 } & \multicolumn{2}{|c|}{ 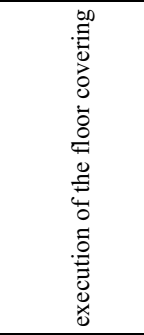 } & \multicolumn{2}{|c|}{ 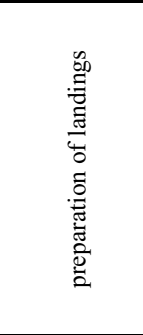 } & \multicolumn{2}{|c|}{ 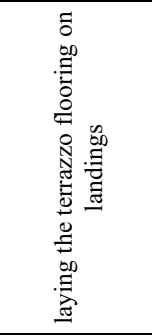 } & \multicolumn{2}{|c|}{ 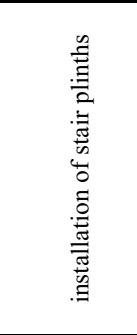 } & \multicolumn{2}{|c|}{ 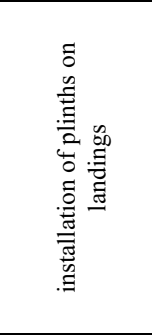 } & \multirow{2}{*}{ 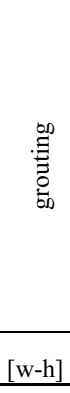 } & \multirow[t]{2}{*}{ 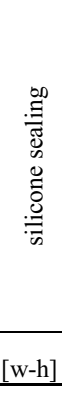 } & \multirow[t]{2}{*}{$\begin{array}{c}\frac{\pi}{6} \\
{[\mathrm{w}-\mathrm{h}]}\end{array}$} \\
\hline & & {$[\mathrm{w}-\mathrm{h}]$} & $\mathrm{m}$ & [w-h] & $\mathrm{m}^{2}$ & {$[\mathrm{w}-\mathrm{h}]$} & $\mathrm{m}^{2}$ & $\mathrm{w}-\mathrm{h}]$ & pc. & [w-h] & $\mathrm{m}$ & & & \\
\hline $\mathrm{A} 1$ & 74.2 & & 17 & 8 & 0.5 & 5.6 & 20.5 & 235 & 140 & 27.9 & 114.2 & 15.8 & 25.1 & 662. \\
\hline $\mathrm{A} 2$ & 3 & 7.9 & 174 & 76 & 120.5 & 15.9 & 120.5 & 243 & 140 & 253 & 114.2 & 39.3 & 23.7 & 534.7 \\
\hline E1 & 53.9 & 8.3 & 174 & .1 & 120.5 & 5.5 & 120.5 & 23.4 & 140 & 29.5 & 114.2 & 37.8 & 22 & 467.5 \\
\hline E2 & 7 & 0.8 & 174 & 30.7 & 120.5 & 104.2 & 120.5 & 051 & 140 & 265 & 114.2 & 39.5 & 25 & 500.5 \\
\hline B1 & 42.8 & 5.5 & 150 & 54 & 1126 & 98.5 & 112.6 & 25. & 14 & 26.2 & 106.7 & 39.2 & 23.6 & 444.8 \\
\hline B2 & 45.0 & 110.0 & 150 & .4 & 112.0 & 1.0 & 112.6 & 24.1 & 14 & 25.5 & 106.7 & 36.7 & 22.3 & 403. \\
\hline D1 & 50.3 & 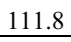 & 15 & Or. & 112.6 & 82.1 & 112.6 & 25 & 2 & . & 66.7 & 36.4 & 24.5 & 419.9 \\
\hline $\mathrm{C} 1$ & 64 & 117.3 & 175 & 66.9 & 135.2 & 104.4 & 135.2 & 31.2 & 10 & 27.3 & 125.6 & 31.4 & 24.2 & 466.7 \\
\hline $\mathrm{C} 2$ & 69.1 & 132.2 & 175 & 15.9 & 135.2 & 104.8 & 135.2 & 21.1 & 100 & 24.2 & 125.6 & 41.1 & 23.8 & 496.2 \\
\hline $\mathrm{D} 2$ & 60.5 & 16.5 & 150 & 65.1 & 112.6 & 88.6 & 112.6 & 24.3 & 140 & 24.3 & 106.7 & 45.6 & 29 & 453 \\
\hline
\end{tabular}


Due to the differences in the measurements of the executed works, a part of the collected times have been reduced using the proportion of the size of performed works on a given staircase in relation to the smallest one. The results of the standardization adjustments are presented in Table 4.

Table 4. Data after standardization

\begin{tabular}{|c|c|c|c|c|c|c|c|c|c|}
\hline 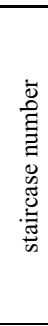 & 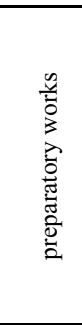 & 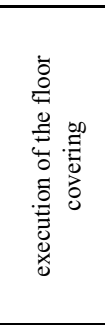 & 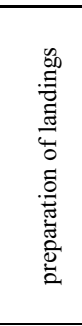 & 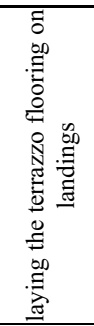 & 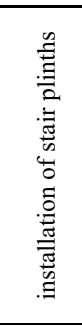 & 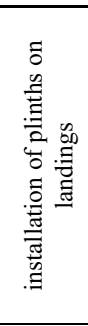 &  & 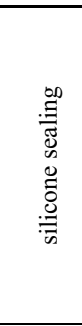 & 氶 \\
\hline & [w-h] & {$[\mathrm{w}-\mathrm{h}]$} & {$[\mathrm{w}-\mathrm{h}]$} & {$[\mathrm{w}-\mathrm{h}]$} & {$[\mathrm{w}-\mathrm{h}]$} & {$[\mathrm{w}-\mathrm{h}]$} & {$[\mathrm{w}-\mathrm{h}]$} & {$[\mathrm{w}-\mathrm{h}]$} & {$[\mathrm{w}-\mathrm{h}]$} \\
\hline A1 & 67.06 & 207.76 & 83.91 & 126.71 & 23.50 & 26.07 & 41.39 & 22.68 & 599.08 \\
\hline $\mathrm{A} 2$ & 65.78 & 136.12 & 71.02 & 108.30 & 24.30 & 23.64 & 35.76 & 21.56 & 486.48 \\
\hline E1 & 49.07 & 119.22 & 62.70 & 89.24 & 23.40 & 27.56 & 34.42 & 20.03 & 425.65 \\
\hline E2 & 53.52 & 121.38 & 75.41 & 97.37 & 25.10 & 24.76 & 36.02 & 22.79 & 456.35 \\
\hline B1 & 42.80 & 135.50 & 54.00 & 98.50 & 25.00 & 26.20 & 39.20 & 23.60 & 444.80 \\
\hline B2 & 45.60 & 116.80 & 53.40 & 81.50 & 24.10 & 23.50 & 36.70 & 22.30 & 403.90 \\
\hline D1 & 50.30 & 111.80 & 64.70 & 82.10 & 25.00 & 25.10 & 36.40 & 24.50 & 419.90 \\
\hline $\mathrm{C} 1$ & 54.15 & 100.54 & 55.72 & 86.95 & 27.30 & 23.19 & 26.57 & 20.48 & 394.90 \\
\hline $\mathrm{C} 2$ & 58.46 & 113.31 & 61.55 & 87.28 & 23.71 & 20.56 & 34.77 & 20.13 & 419.78 \\
\hline D2 & 60.50 & 116.50 & 65.10 & 88.60 & 24.30 & 24.30 & 45.60 & 29.00 & 453.90 \\
\hline
\end{tabular}

\subsection{Pert calculations}

The prepared data shown in Table 4 were subsequently used in calculations performed according to formulas 1, 2 and 3 . The optimistic time a was defined as the shortest one occurring in a given column. The pessimistic time $\mathrm{b}$ is the greatest value in a column. The arithmetic mean of the collected results was used to determine the most probable one $-\mathrm{m}$. For illustration of the possibility to determine the time of task completion with probability $\mathrm{P}=85 \%$, factor $\mathrm{W}=1.07$ was adopted. The results of the calculations are presented in Table 5 . 
Table 5. Parameters of the PERT method

\begin{tabular}{|c|c|c|c|c|c|c|c|c|c|}
\hline 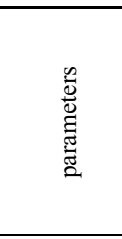 & 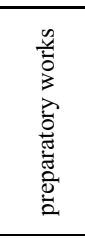 & 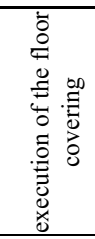 & 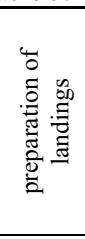 & 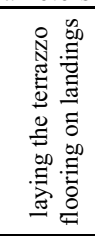 & 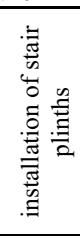 & 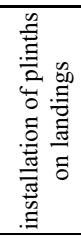 & 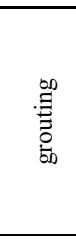 & 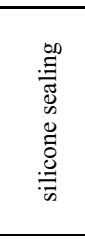 & సٓ \\
\hline a & 42.80 & 100.54 & 53.40 & 81.50 & 23.40 & 20.56 & 26.57 & 20.03 & 394.90 \\
\hline$b$ & 67.06 & 207.76 & 83.91 & 126.71 & 27.30 & 27.56 & 45.60 & 29.00 & 599.08 \\
\hline $\mathrm{m}$ & 54.72 & 127.89 & 64.75 & 94.65 & 24.57 & 24.49 & 36.68 & 22.71 & 450.47 \\
\hline$t_{p}$ & 54.79 & 136.65 & 66.05 & 97.80 & 24.83 & 24.35 & 36.48 & 23.31 & 465.98 \\
\hline$\sigma^{2}$ & 16.34 & 319.31 & 25.86 & 56.78 & 0.42 & 1.36 & 10.06 & 2.23 & 1158.03 \\
\hline $\mathrm{T}(\mathrm{P}=85 \%)$ & 59.12 & 155.77 & 71.49 & 105.87 & 25.53 & 25.59 & 39.88 & 24.91 & 502.39 \\
\hline
\end{tabular}

It may be concluded on the basis of the above calculations that the safe time to be assumed for the execution of a staircase consisting of $150 \mathrm{~m}$ of steps, $112.6 \mathrm{~m} 2$ of landings, 140 sets of plinths on the steps and $106.7 \mathrm{~m}$ of plinths on landings is 502.39 man-hours. The value was determined with probability $\mathrm{P}=85 \%$. This value offers a high level of reliability.

\subsection{THE PERT METHOD COMPARED TO THE CALCULATIONS BASED ON THE KNR}

Katalogi Nakładów Rzeczowych /Material Expenditure Catalogues/ are the most popular data bases used to estimate the time of realization of works. They contain data related to the average labour input needed to perform a measuring unit of a given work. Unfortunately, they do not cover all works and all possible technologies. Using the KNR, it is frequently necessary to base the estimation on the data referring to a similar activity rather than the exact one we are interested in.

The duration of the staircase flooring task, which was subject of the research presented in chapter 3.2, was also estimated with the use of the method based on the KNR. The current catalogues of the company providing materials and technology for laying the floors in the construction project under consideration $[3,4]$ were used for this purpose. Given the absence of flooring made of ready tiles and steps made of terrazzo in the KNR, ceramic flooring, very similar in technology of execution, had to be used as a substitute. It should be highlighted that terrazzo elements are thicker and heavier than ceramic tiles described in the KNR, which should be reflected in the amount of labour required for the execution of flooring. The relevant data and calculations are shown in Table 6. 
Table 6. Labour inputs to execute a sample staircase

\begin{tabular}{|c|l|c|c|c|c|}
\hline $\begin{array}{c}\text { Base } \\
\text { number }\end{array}$ & \multicolumn{1}{|c|}{ Description table } & Unit & $\begin{array}{c}\text { Circulation } \\
\text { unit }\end{array}$ & $\begin{array}{c}\text { The value of } \\
\text { quantity } \\
\text { survey }\end{array}$ & Time \\
\hline DC-20 & $\begin{array}{l}\text { TABLE 0319 - ceramic tiles suitable to be } \\
\text { laid in the staircase (with certain allowance) }\end{array}$ & $\mathrm{m}$ & 1.45 & 150 & 217.50 \\
\hline DC-20 & $\begin{array}{l}\text { TABLE 0318 - Plinths of non-absorbent } \\
\text { ceramic tiles (landings) }\end{array}$ & $\mathrm{m}$ & 0.51 & 106.7 & 54.42 \\
\hline DC-20 & $\begin{array}{l}\text { TABLE 0318 - Plinths of non-absorbent } \\
\text { ceramic tiles (stairs) }\end{array}$ & $\mathrm{m}$ & 0.7 & 65.8 & 46.06 \\
\hline DC-20 & $\begin{array}{l}\text { TABLE 0314 - Ceramic tiles of final non- } \\
\text { absorbent surfaces }\end{array}$ & $\mathrm{m}^{2}$ & 2.01 & 112.6 & 226.33 \\
\hline DC-19 & $\begin{array}{l}\text { TABLE 0101 - Primer for absorbent } \\
\text { substrates }\end{array}$ & $\mathrm{m}^{2}$ & 0.15 & 200.35 & 30.05 \\
\hline DC-19 & $\begin{array}{l}\text { TABLE 0212 - Filling the voids } \\
\text { (reprofiling) in the surface of concrete grout } \\
\text { (with certain allowance) }\end{array}$ & $\mathrm{m}^{2}$ & 0.44 & 112.6 & 49.54 \\
\hline DC-19 & $\begin{array}{l}\text { TABLE 0418 - Filling weight silicone } \\
\text { joints }\end{array}$ & $\mathrm{m}$ & 0.14 & 322.5 & 45.15 \\
\hline
\end{tabular}

In order to perform calculations, appropriate allowances had to be made to accommodate greater thickness of adhesive mortar. The catalogues included all preparatory works, according to their description. The obtained amount of effort required to execute the staircase is much larger than the actual results. The disadvantage of using the KNR is that what you get is the exact result, and no information is given allowing you to determine the probability of the result. Besides, it does not take into account the size of fronts, workers' skills or other factors affecting the task completion time.

\section{SUMMARY}

There are many methods for estimating working time. We can distinguish e.g. the parametric, probabilistic or empirical one among them. The PERT method is based on the actual completion time of the task, which makes it possible to determine the deadline with the assumed probability. It is therefore a lot more reliable than the KNR-based method. The completion time determined on the basis of the KNR is grossly overestimated and far from reliable.

The approach to estimating the time of task completion presented in this article will continue to be developed. The research on time estimation is still in progress and the authors are looking for solutions to build a mathematical model describing the working time of construction workers. 


\section{REFERENCES}

1. Boehm, B., Abts, C., Brown, W., Chulani, S., Clark, B., Horowitz, E., ... Madachy, R. Software Cost Estimation with COCOMO II. Nowy Jork: Prentice-Hall, 2000.

2. Cooke, B. i Williams, P. Construction planning, programming and control. New Jersey: Wiley-Blackwell, 2009.

3. Datacomp Polska, Katalog Nakładów Rzeczowych. Systemy linii budowlanej MAPEI DC-19, Kraków 2011.

4. Datacomp Polska, Katalog Nakładów Rzeczowych. Okładziny z płytek ceramicznych w systemie MAPEI DC-20, Kraków 2011.

5. Helmer, O. Social Technology. New York: Basic Books 1966.

6. Hendrickson C., Au T., Project Management for Construction, Prentice Hall, International Edition 1989.

7. Juszczyk M., Malara J. Probabilistic approach to duration assessment for selected construction works. Creative Construction Conference 2015. Materiały konferencyjne (w druku), 2015.

8. Karner, G. , Use Case Points - Resource Estimation for Objectory Projects. AB: Objective Systems SF, 1993.

9. Kuprenas, J., Influence of construcion costs on schedule performance. CHALLENGES AND SOLUTIONS IN STRUCTURAL ENGINEERING AND CONSTRUCTION, 1, p.903-905, 2010.

\section{LIST OF FIGURES AND TABLES:}

Tab. 1. Estimated parameters of triangular and normal distribution of the construction works duration.

Tab. 1. Parametry estymacji rozkładu normalnego I trójkątnego czasu trwania prac budowlanych.

Tab. 2. Assumed durations and their probabilities.

Tab. 2. Założone czasy trwania czynności i ich prawdopodobieństwo .

Diagram 1. The sequence of steps in the adopted technology.

Wykres 1. Kolejność technologiczna wykonywanych czynności.

Tab. 3. Data obtained from research.

Tab. 3. Dane na podstawie wyników badań.

Tab. 4. Data after standardization.

Tab. 4. Dane po standaryzacji.

Tab. 5. Parameters of the PERT method.

Tab. 5. Parametry metody PERT.

Tab. 6. Labour inputs to execute a sample staircase

Tab. 6. Nakłady pracy przy wykonaniu przykładowej klatki schodowej. 


\section{SZACOWANIE CZASÓW REALIZACJI ZADAŃ Z WYKORZYSTANIEM METODY PERT NA PRZYKLADZIE KONKRETNEJ REALIZACJI}

Slowa kluczowe: Metoda PERT, czas pracy.

\section{STRESZCZENIE:}

W artykule przedstawiono kilka metod szacowania czasu pracy: metoda delficka, COCOMO II, Use Case Points, PERT, Katalogi Nakładów Rzeczowych i matematyczne funkcje rozkładu prawdopodobieństwa. We wstępie teoretycznym po krótce omówiono podstawy każdej z nich. Metoda delficka jest metodą heurystyczną, opartą na doświadczeniach ekspertów. Przewidywana prognoza prawdopodobieństwa realizacji zadania określona zostaje na podstawie serii ankiet. COCOMO II jest modelem służącym do oszacowania nakładu pracy. Wyniki zostały opracowane na podstawie analizy ponad 60 projektów. Metoda Use Case Points pochodzi z metody punktów funkcyjnych. Przy wykorzystywaniu tej metody bierze się pod uwagę czynniki środowiskowe, czynniki złożoności technicznej projektów, osoby realizujące projekt w zestawieniu z rzeczywistymi pomiarami. Wśród metod sieciowych opisanym przypadkiem jest PERT (Program Evaluation and Review Technique). Należy ona do grupy deterministycznych, opartych na znalezieniu ścieżki krytycznej (podobnie jak wCPM), a następnie ustaleniu parametrów rozkładu prawdopodobieństwa: optymistycznego czasu zakończenia zadania (a), najbardziej prawdopodobnego czasu zakończenia zadania (m) i pesymistycznego czasu zakończenia zadania (b). Z uwagi na jej charakter można $z$ łatwością stosować metody statystyczne do oceny ryzyka dotrzymania terminu realizacji zadań. Ostatnią omówioną metodą szacowania czasów realizacji są Katalogi Nakładów Rzeczowych. Jest to podejście najczęściej wykorzystywane przez polskich kosztorysantów, gdzie nakłady zestawione są w sposób tabelaryczny i przypisane do konkretnej roboty budowlanej. Obliczenia przedstawione $\mathrm{w}$ artykule zostały wykonane $\mathrm{z}$ wykorzystaniem trzech metod, na podstawie wyników badań obserwacji pracowników wykonujących okładziny klatek schodowych z lastryko. Badania realizowano w Warszawie, przy budowie osiedla mieszkaniowego składającego się z dziesięciu bardzo podobnych klatek schodowych. Wszystkie roboty były wykonywane przez tę samą brygadę (ci sami pracownicy). W trakcie prowadzenia badań zostało wyszczególnionych osiem czynności: prace przygotowawcze, układanie stopni, wyrównanie spoczników i korytarzy, układanie spoczników i korytarzy, montaż cokołów przy schodach, montaż cokołów na spocznikach i korytarzach, fugowanie i silikonowanie. Kolejność wykonania powyższych prac została przedstawiona na grafie. Dla każdej z czynności na każdej z klatek schodowych został ustalony nakład pracy. Pierwsze przedstawione obliczenia prezentują zastosowanie matematycznych funkcji rozkładu normalnego i trójkątnego do szacowania czasów realizacji. Na podstawie obliczeń określone zostało prawdopodobieństwo realizacji trzech czynności (układania stopni, wyrównania spoczników i korytarzy, układania lastryka na spocznikach i korytarzach). Nie stwierdzono dużych różnic pomiędzy wynikami z zastosowaniem rozkładu trójkątnego, a normalnego. Najbardziej szczegółowo przeprowadzone zostały obliczenia z wykorzystaniem metody PERT. Pierwszym etapem obliczeń była standaryzacja wyników. Etap ten był konieczny z uwagi na różnice obmiarowe pomiędzy klatkami schodowymi. Na podstawie proporcji wszystkie wartości pomiarowe zostały odpowiedni zmniejszone lub powiększone, co pozwoliło na dalsze porównywanie wartości i ich obiektywną analizę. Następnie obliczono wartości charakterystyczne dla metody (czasy a,m,b). Kolejnym krokiem było ustalenie czasów realizacji poszczególnych czynności składowych, jak również i całego zadania z prawdopodobieństwem sukcesu na poziomie $85 \%$. Dla tych danych ustalono czas realizacji przykładowej klatki schodowej w 502,39 roboczo-godziny. Przykład 
wykorzystany do obliczeń metoda PERT został również oszacowany z wykorzystaniem KNR. Na podstawie Katalogów opracowanych do prac posadzkarskich zostało znalezionych siedem odpowiednich czynności (prace przygotowawcze były rozbite $\mathrm{w}$ każdej $\mathrm{z}$ nich). Na podstawie odszukanych nakładów pracy dokonano obliczeń uwzględniając wystandaryzowaną do metody PERT klatkę schodową. Uzyskany w ten sposób czas - 669,05 roboczo-godziny był dużo większy w stosunku do metody PERT. Należy zaznaczyć, że w KNR wykorzystywane są czasy średnie (P=50\%). $\mathrm{W}$ podsumowaniu zaznaczono przewagę metody PERT nad innymi ze względu na zawarte w niej elementy probabilistyki jak i możliwość wykorzystania rzeczywistych czasów realizacji wynikających z przeprowadzonych badań. Zadeklarowana również została kontynuacja badań nad czasem pracy robotników budowlanych, która zakończy się zbudowaniem stosownego modelu matematycznego uwzględniającego czynniki wpływające na czas pracy i wydajność robotników budowlanych. 